JOSING: Journal of Nursing and Health

Volume 2, Nomor 2, Juni 2022

e-ISSN: 2745-7877

p-ISSN: 2746-0851

DOI: https://doi.org/10.31539/josing.v2i2.3485

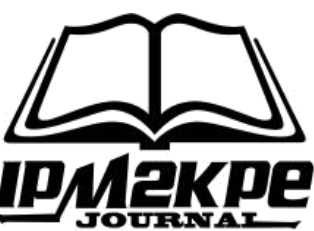

\title{
PROGRESSIVE MUSCLE RELAXATION (PMR) INTERVENTION WITH SLOW DEEP BREATHING EXERCISE (SDBE) ON BLOOD PRESSURE OF HYPERTENSION PATIENTS
}

\author{
Andry Sartika ${ }^{1}$, Juli Andri ${ }^{2}$, Padila ${ }^{3}$ \\ Muhammadiyah University of Bengkulu ${ }^{1,2,3}$ \\ padila@umb.ac.id ${ }^{3}$
}

\begin{abstract}
This study aims to determine the difference between Intervention Effectiveness Progressive Muscle Relaxation (PMR) and Slow Deep Breathing Exercise (SDBE) in TD patients with hypertension. This type of research is an experimental design with a randomized pre-test and post-test three-group design without a control group. The results showed that there was a decrease in systolic and diastolic BP after the intervention in all groups. There was no significant difference in effectiveness between the three groups after the intervention; the optimal time to decrease systolic BP in the PMR and SDBE groups occurred on day 3. On the other hand, the diastolic BP does not show time. Optimal BP reduction. The conclusion of the three relaxation techniques effectively reduces blood pressure in patients with hypertension. Adequate time to lower blood pressure occurs on the third day.
\end{abstract}

Keywords: Hypertension, Progressive Muscle Relaxation (PMR), Slow Deep Breathing Exercise (SDBE), Blood Pressure

\section{INTRODUCTION}

Blood pressure is one of the factors that have a significant influence on the circulatory system. High blood pressure or low blood pressure affects the body's homeostasis (Andri et al., 2021; Andari et al., 2020; Zainuddin et al., 2018). The group of non-communicable diseases that are very common and easily detected in the community is hypertension or high blood pressure (Permata et al., 2021; Wulandari \& Puspita, 2019). Hypertension is a condition in which the blood pressure in the arteries is too high. Hypertension, otherwise called "quiet executioner," is a not kidding general medical condition worldwide with an age-normalized commonness of $24.1 \%$ in men and $20.1 \%$ in ladies, separately. Hypertension is an important risk factor for cardiovascular disease, renal, and eye diseases (Shrestha et al., 2021). The number of people with hypertension every year around the world continues to increase. In 2012 Cardiovascular Disease (CVD) killed 17.5 million people, equivalent to every 3 out of 10 deaths, of these 17 million deaths in a year more than 9.4 million were caused by complications of hypertension which also often called increased high blood pressure (Sartika et al., 2020).

The World Health Organization (WHO) in 2015 showed that around 1.13 billion people worldwide suffer from hypertension, meaning that 1 in 3 people in the world is diagnosed with hypertension. The number of people with hypertension continues to increase every year. It is not expected that in 2025 , there will be 1.5 Billion. In Southeast Asia, including Indonesia, it was reported that $49.7 \%$ of the causes of death were due to non-communicable diseases, one of which was hypertension (Sartika et al., 2018; Irawan, 
2017). In Indonesia, it is estimated that the number of hypertension cases in Indonesia is $63,309,620$ people, while the death rate in Indonesia due to hypertension is 427,218 deaths. Hypertension occurs in the age group 31-44 years (31.6\%), age 45-54 years (45.3\%), age 55-64 years (55.2\%) (Andri et al., 2021; Kementerian Kesehatan RI, 2018). This cardiovascular disease condition occurs with age where there is a decrease in the elasticity of the arterial walls and stiffness in the systemic blood vessels due to aging (Harsismanto et al., 2020; Sudarso et al., 2019)

The prevalence of hypertension in Bengkulu Province based on the 2018 rikesdas was reported as 11,373 people aged 18 years. Hypertension occurs mostly in the 25-34 year age group, occurs in male sex and in rural areas. One of the districts in Bengkulu Province is Kepahiang district, which has 14 health centers. The number of cases of hypertension at the age of 18 years according to gender in 2017 was reported as many as 800 people (Tim Riskesdas, 2019; Andri et al., 2018).

Hypertension is a common problem that, if left untreated, can lead to significant complications, including those involving the cardiovascular system and end organs. Approximately $10 \%$ of patients with hypertension are classified as secondary hypertension, defined as hypertension due to a specific and potentially correctable cause. The causes can be broadly categorized as endocrine (e.g., hyperaldosteronism, pheochromocytoma, hyperparathyroidism) and nonendocrine (e.g., coarctation of the aorta, renal vascular hypertension). In addition, patients with hypertension may experience significant complications that are also diagnosed by imaging, including conditions involving the cardiovascular system (e.g., aortic aneurysm, acute aortic syndrome) and central nervous system (e.g., stroke, subarachnoid hemorrhage, and posterior reversible encephalopathy syndrome) (Siddiqui et al., 2019).

Hypertension is a classic cardiovascular risk factor with direct effects on the heart and great vessels. Not only affects the development of heart failure, atrial fibrillation, ischemic heart disease, and aortic valve disease but poor blood pressure control also carries a poor prognosis for patients with heart disease (Al-Mahdi et al., 2021). Hypertension is arguably a non-communicable cardiovascular risk factor. Target organ damage such as coronary artery disease, chronic kidney disease, heart failure, and stroke is relatively common among those with uncontrolled hypertension (Oni et al., 2020).

Early treatment of hypertension is very important because it can prevent various complications. Pharmacological treatment of hypertension, the drugs used include betablockers, angiotensin converting enzyme inhibitors, angiotensin receptor blockers, diuretics, and calcium channel blockers (Paduszyńska et al., 2020).

Hypertension (HTN) is a pathological condition characterized by persistently reading blood pressure (BP) higher than 139x89mmHg. Treatment includes a non-pharmacological approach for all types, regardless of BP, where the primary goal is to reduce cardiovascular morbidity and mortality with lifestyle changes (Moura, 2019). One of the nonpharmacological therapies in lowering blood pressure is relaxation techniques. The relaxation method can control the nervous system which is useful for lowering blood pressure. The basic concept of relaxation techniques is essentially a way of relaxation that is needed to reduce tension in muscles that can improve pulse, blood pressure, and breathing (Atmojo et al., 2019).

Relaxation techniques on high blood pressure have had positive effects that have been proven by many researchers, one of which is Progressive Muscle Relaxation (PMR). PMR is a method to help reduce muscle so that the body becomes relaxed (Rosdiana \& Cahyati, 
2019). Some of the features of this progressive muscle relaxation technique are reducing muscle tone, headache, headache, back pain, heart rate, respiratory rate, metabolic rate, lowering pulse rate, lowering systolic and diastolic blood pressure and reducing stress in the elderly, reducing depression anxiety by increasing self-control (Akhriansyah, 2019).

In addition to Progressive Muscle Relaxation (PMR), another relaxation intervention is Slow Deep Breathing Exercise (SDBE). Slow Deep Breathing Exercise (SDBE) is a breathing technique with a less than 10x/minute respiration frequency and a long inhalation phase. The benefit of this slow deep breathing exercise is to reduce pain and stress levels, to control tension and fear. If the correct technique in doing slow deep breathing exercises can have a relaxing effect with regular breathing rules (Febrianingrum et al., 2021).

Previous studies have researched the effect of deep breathing relaxation on changes in blood pressure in hypertensive patients. The results showed a significant decrease in blood pressure after deep breathing relaxation. Researchers concluded that deep breathing relaxation techniques could also reduce blood pressure in hypertensive patients through relaxation exercises. Based on the above background, the purpose of this study was to determine the differences in the effectiveness of Progressive Muscle Relaxation (PMR) and Slow Deep Breathing Exercise (SDBE) on the BP of hypertensive patients.

\section{RESEARCH METHOD}

The type of experimental study was a randomized pretest and posttest three group design without a control group where the researcher compared the differences in the effectiveness of progressive muscle relaxation with a slow deep breathing exercise on blood pressure in patients with hypertension, and the intervention group was divided into three with different treatments. The sample in this study were patients with hypertension in the working area of the Kepahiang Bengkulu district health center totaling 30 people.

The research was conducted in the working area of the Health Center Kepahiang Bengkulu Regency, namely Pasar Kepahiang Public Health Center, Kabawetan Health Center, and Bukit Sari Health Center. Data collection tools used assessment questionnaires and observation sheets, digital sphygmomanometer, PMR and SDBE training guides, watches, computer documentaries to store and process research results using the SPSS program.

\section{RESULTS \\ Characteristics of Respondents}

Table. 1

Distribution of Respondents by Age $(n=30)$

\begin{tabular}{cccccc}
\hline Variable & Group & $\mathrm{n}$ & Mean & SD & Min Max \\
\hline \multirow{3}{*}{ Age } & PMR & 10 & 46,10 & 7,58 & $35-57$ \\
& SDBE & 10 & 49,50 & 7,17 & $39-57$ \\
& SDBE PMR & 10 & 44,90 & 7,04 & $35-56$ \\
\hline
\end{tabular}

From the table above, it can be seen that the age frequency distribution of respondents in the PMR group is 35 years old and the highest is 57 years old, the lowest age is 39 years in the SDBE group, and the highest age is 57 years, while the SDBE and PMR groups are 35 years old and the highest age is 56 . year. 
Table. 2

Distribution of Respondents by Gender, Family History, Smoking History of Patients with Hypertension $(n=30)$

\begin{tabular}{|c|c|c|c|c|c|}
\hline \multirow[t]{2}{*}{ Data Type } & \multicolumn{3}{|c|}{ Frequency Group } & \multirow[t]{2}{*}{ (n) } & \multirow[t]{2}{*}{$(\%)$} \\
\hline & SDBE & PMR & SDBEPMR & & \\
\hline \multicolumn{6}{|l|}{ Gender } \\
\hline Male & 7 & 4 & 8 & 19 & 63,3 \\
\hline Female & 3 & 6 & 2 & 11 & 36,7 \\
\hline tal & 10 & 10 & 10 & 30 & 100 \\
\hline \multicolumn{6}{|l|}{ mily History } \\
\hline None & 3 & 3 & 2 & 8 & 26,7 \\
\hline Exist & 7 & 7 & 8 & 22 & 73,3 \\
\hline tal & 10 & 10 & 10 & 30 & 100 \\
\hline \multicolumn{6}{|l|}{ oking History } \\
\hline No Smoking & 3 & 5 & 2 & 10 & 33,3 \\
\hline Smoking & 7 & 5 & 8 & 20 & 66,7 \\
\hline Total & 10 & 10 & 10 & 30 & 100 \\
\hline
\end{tabular}

From the table above, it can be seen that the frequency distribution of respondents based on gender, most of the respondents were male, as many as 19 respondents $(63.3 \%)$. Respondents who have a family history of hypertension are mostly 22 respondents $(73.3 \%)$, and respondents who have a history of smoking are mostly 20 respondents $(66.7 \%)$.

Table. 3

Description of the Average Systolic and Diastolic Blood Pressure of Respondents Before and After Intervention in the PMR Group $(n=10)$

\begin{tabular}{clllc}
\hline \multicolumn{1}{c}{ BP } & Intervensi & Mean & SD & Min-Maks \\
\hline \multirow{2}{*}{ Sistolic } & Pre & 158,32 & 8,65 & $146,21-172,14$ \\
& Post & 156,92 & 8,91 & $144,50-172,14$ \\
\hline \multirow{2}{*}{ Diastolic } & Pre & 89,82 & 3,38 & $86,21-93,93$ \\
& Post & 88,87 & 3,73 & $84,43-93,71$ \\
\hline
\end{tabular}

Based on the table above, the average value of systolic blood pressure before the PMR intervention was $158.32 \mathrm{mmHg}$, and after the intervention was $156.92 \mathrm{mmHg}$. Meanwhile, the average diastolic blood pressure was $88.92 \mathrm{mmHg}$ before the PMR intervention and $88.87 \mathrm{mmHg}$ after the intervention

Table. 4

Description of Average Systolic and Diastolic Blood Pressure of Respondents Before and After Intervention in the SDBE Group $(n=10)$

\begin{tabular}{ccccc}
\hline BP & Intervensi & Mean & SD & Min-Maks \\
\hline \multirow{2}{*}{ Sistolic } & Pre & 160,07 & 8,28 & $146,64-171,64$ \\
& Post & 158,07 & 8,00 & $145,00-171,64$ \\
\hline \multirow{2}{*}{ Diastolic } & Pre & 91,21 & 5,98 & $84,79-101,43$ \\
& Post & 89,36 & 6,18 & $82,71-99,00$ \\
\hline
\end{tabular}

Based on the table above, the average value of systolic blood pressure before the SDBE intervention was $160.07 \mathrm{mmHg}$ and after the intervention was $158.07 \mathrm{mmHg}$. Meanwhile, the average diastolic blood pressure was $91.21 \mathrm{mmHg}$ before the PMR 
intervention and $89.36 \mathrm{mmHg}$ after the intervention

Table. 5

Overview of Respondents' Average Systolic and Diastolic Blood Pressure Before and After Interventions in the SDBE PMR Group ( $\mathrm{n}=10)$

\begin{tabular}{ccccc}
\hline BP & Intervention & Mean & SD & Min-Maks \\
\hline \multirow{2}{*}{ Sistolic } & Pre & 154,95 & 8,44 & $144,79-169,93$ \\
& Post & 152,70 & 8,17 & $143,07-165,50$ \\
\hline \multirow{2}{*}{ Diastolic } & Pre & 93,90 & 6,77 & $87,07-104,86$ \\
& Post & 92,97 & 7,43 & $85,86-104,79$ \\
\hline
\end{tabular}

Based on the table above, the average value of systolic blood pressure before the SDBE PMR intervention was $154.95 \mathrm{mmHg}$ and after the intervention was $152.70 \mathrm{mmHg}$. Meanwhile, the average diastolic blood pressure was $93.90 \mathrm{mmHg}$ before the PMR intervention and $92.97 \mathrm{mmHg}$ after the intervention.

Table. 6

Wilcoxon Sign Rank Test Results Mean Systolic and Diastolic Blood Pressure Before and After PMR Intervention $(\mathrm{n}=10)$

\begin{tabular}{llccc}
\hline \multicolumn{1}{c}{ BP } & Intervensi & Mean & SD & P Value \\
\hline \multirow{2}{*}{ Sistolic } & Pre & 158,32 & 8,66 & \multirow{2}{*}{0,013} \\
& Post & 156,92 & 8,91 & \\
\hline \multirow{2}{*}{ Diastolic } & Pre & 89,82 & 3,38 & \multirow{2}{*}{0,005} \\
& Post & 88,89 & 3,73 & \\
\hline
\end{tabular}

There is a significant difference between systolic blood pressure before and after the intervention with a p-value $=0.013$. The average diastolic blood pressure also has a significant difference between diastolic blood pressure before and after the intervention, with a $\mathrm{p}$-value $=0.005$.

Table. 7

Wilcoxon Sign Rank Test Results Mean Systolic and Diastolic Blood Pressure Before and After SDBE Intervention $(\mathrm{n}=10)$

\begin{tabular}{lcccc}
\hline \multicolumn{1}{c}{ BP } & Intervensi & Mean & SD & P Value \\
\hline \multirow{2}{*}{ Sistolic } & Pre & 160.08 & 8,28 & \multirow{2}{*}{0,005} \\
& Post & 158,08 & 6,18 & \\
\hline \multirow{2}{*}{ Diastolic } & Pre & 91,22 & 5,98 & \multirow{2}{*}{0,005} \\
& Post & 89,36 & 6,18 & \\
\hline
\end{tabular}

There is a significant difference between systolic blood pressure before and after the intervention with a $\mathrm{p}$-value $=0.005$, and the average diastolic blood pressure also has a significant difference between diastolic blood pressure before and after the intervention with a $\mathrm{p}$-value $=0.005$. 
Table. 8

Wilcoxon Sign Rank Test Results Mean Blood Pressure and Diastolic Before and After SDBE PMR Intervention $(n=10)$

\begin{tabular}{ccccc}
\hline \multicolumn{1}{c}{ BP } & Intervensi & Mean & SD & P Value \\
\hline \multirow{2}{*}{ Sistolic } & Pre & 154,95 & 8,44 & \multirow{2}{*}{0,005} \\
& Post & 152,70 & 8,18 & \\
\multirow{2}{*}{ Diastolic } & Pre & 93,90 & 6,77 & \multirow{2}{*}{0.037} \\
& Post & 92,98 & 7,43 & \\
\hline
\end{tabular}

In the Wilcoxon Sign Rank Test, there was a significant difference between the systolic blood pressure values before and after the SDBE PMR intervention with p-value = 0.005 , and in diastolic blood pressure, there was also a significant difference between the diastolic blood pressure values before and after the SDBE PMR with p-value $=0.037$

Table. 9

Results of the Mann-Whitney U Test Mean Difference in Systolic and Diastolic Blood Pressure Between Interventions PMR with SDBE on Blood Pressure of Hypertensive Patients $(n=20)$

\begin{tabular}{|c|c|c|c|c|}
\hline $\mathrm{BP}$ & Intervensi & Mean Rank & $S D$ & $P$ Value \\
\hline Sistolic & $\begin{array}{l}\text { Pre } \\
\text { Post }\end{array}$ & $\begin{array}{c}9,65 \\
11,35\end{array}$ & 1,37 & 0,520 \\
\hline Diastolic & $\begin{array}{l}\text { Pre } \\
\text { Post }\end{array}$ & $\begin{array}{c}7,95 \\
13,95\end{array}$ & 0,70 & 0,009 \\
\hline
\end{tabular}

The statistical test results showed no significant difference in the average decrease in systolic blood pressure between respondents who received PMR therapy and respondents who received SDBE therapy, which means that the average systolic blood pressure between the two groups was the same. In diastolic blood pressure, the statistical test results showed a significant difference in the average value of diastolic blood pressure between the PMR intervention and the SDBE intervention after the intervention'

Table. 10

Mann-Whitney U Test Results Mean Differences in Blood Pressure Between PMR Interventions and SDBE PMR on Blood Pressure of Patients with Hypertension $(n=20)$.

\begin{tabular}{ccccc}
\hline TD & Intervensi & Mean Rank & SD & P Value \\
\hline \multirow{2}{*}{ Sistolic } & PMR & 8,90 & \multirow{2}{*}{1,29} & 0,226 \\
& SDBE PMR & 12,10 & & \multirow{2}{*}{0,970} \\
Diastolic & PMR & 10,55 & 0,87 & 0,970 \\
\hline
\end{tabular}

The statistical test results showed no significant difference in the decrease in the average value of systolic blood pressure between the PMR intervention and the SDBE PMR intervention after the intervention, which means that the change in systolic blood pressure between the two groups was on average the same. On diastolic blood pressure between the PMR intervention and the SDBE PMR intervention, the statistical test results also found no significant difference in the mean systolic blood pressure between the PMR intervention and the SDBE PMR intervention, which means that the changes in diastolic blood pressure between the two groups are on average the same. 
Table. 11

Mann-Whitney U Test Results Mean Blood Pressure Differences between SDBE and Interventions SDBE PMR on Blood Pressure of Patients with Hypertension $(n=20)$

\begin{tabular}{|c|c|c|c|c|}
\hline $\mathrm{BP}$ & Intervensi & Mean Rank & $S D$ & $P$ Value \\
\hline Sistolic & $\begin{array}{c}S D B E \\
S D B E P M R\end{array}$ & $\begin{array}{c}9,45 \\
11,55\end{array}$ & 1,29 & 0,427 \\
\hline Diastolic & $\begin{array}{c}S D B E \\
\text { SDBE PMR }\end{array}$ & $\begin{array}{c}13,35 \\
7,65\end{array}$ & 0,98 & 0,031 \\
\hline
\end{tabular}

The statistical test results showed no significant difference in the average decrease in systolic blood pressure between the SDBE intervention and the SDBE PMR intervention after the intervention was given. This means that the change in systolic blood pressure between the two groups is, on average, the same. The statistical test results showed a difference in diastolic blood pressure between the SDBE intervention and the SDBE PMR intervention after the intervention. There was a significant decrease in the mean diastolic blood pressure between the SDBE intervention and the SDBE PMR intervention after the intervention.

waktu

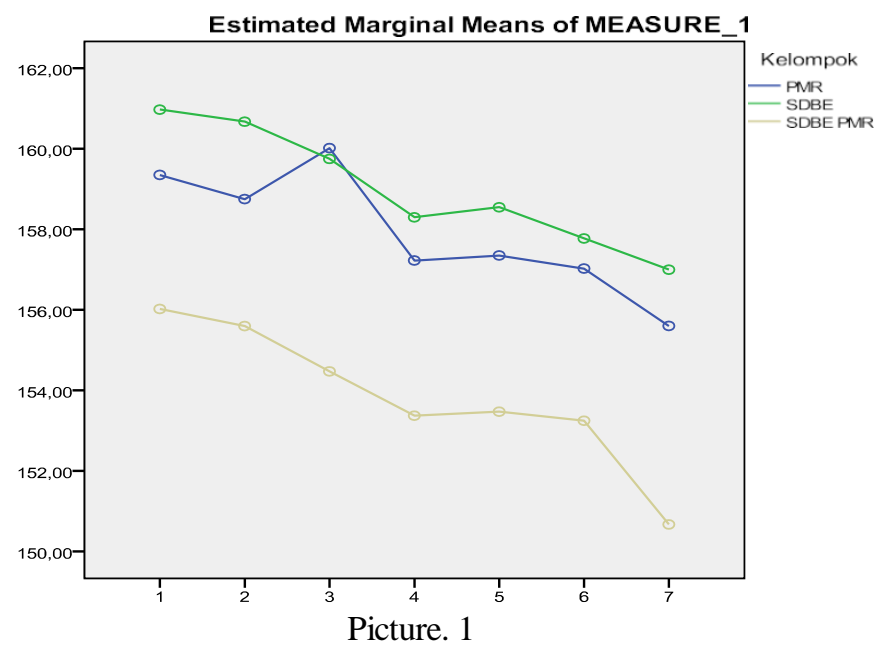

Plot General Linear Model-Repeated Measures (GLM-RM)

Systolic Blood Pressure ( $\mathrm{n}=30)$

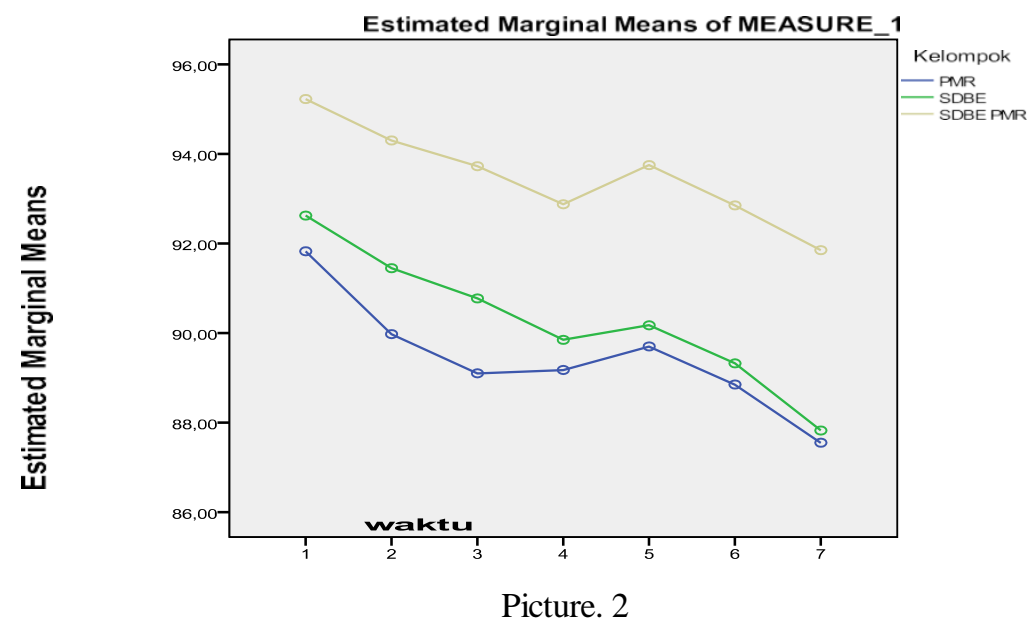

Plot General Linear Model-Repeated Measures (GLM-RM) Systolic Blood Pressure ( $\mathrm{n}=30)$ 


\section{DISCUSSION}

The administration of non-pharmacological techniques of PMR, SDBE, and SDBE PMR to patients with hypertension for seven days in this study could significantly reduce systolic and diastolic blood pressure. The provision of PMR relaxation techniques is in line with research (Nurman, 2017), that there is a significant difference in decreasing systolic and diastolic blood pressure given PMR therapy to patients with hypertension, the difference is due to ACTH (adrenocorticotropic hormone) and CRH (corticotrophinreleasing hormone) in the adrenal glands. Hypothalamus decreased. The decrease in the secretion of these two hormones causes the activity of the sympathetic nerves to fall so that the release of the hormones adrenaline and noradrenaline decreases, resulting in a decrease in heart rate, dilation of blood vessels, reduced vascular resistance, and a decrease in heart pump so that the arterial blood pressure of the heart decreases. Most of the respondents said that after the intervention of muscle relaxation therapy, they felt that their muscles felt more relaxed, their body became fresher

The provision of SDBE non-pharmacological technique therapy is in line with research conducted, which states that SDB exercise can cause an increase in cardiopulmonary strain. Stimulation of stretching in the aortic arch and carotid sinus is received and transmitted by the vagus nerve to the medulla oblongata (cardiovascular regulation center), which response to an increase in baroreceptor reflexes (Anggreini \& Alfianur, 2021). Afferent impulses from the baroreceptors reach the heart center, which stimulates parasympathetic nerve activity and inhibits the sympathetic center, causing vasodilation, decreased heart rate, and contraction power. The parasympathetic nervous system that travels to the SA node via the vagus nerve releases the neurotransmitter acetylcholine, which inhibits the rate of depolarization of the SA node, resulting in a decrease in heart rate.

The concurrent use of non-pharmacological therapy using SDBE PMR has also been shown to reduce blood pressure in patients with hypertension. The results of this study follow the research results (Setyaningrum et al., 2018). The results of his research indicate that the PMRS DBE technique, which is carried out simultaneously, can be used to lower blood pressure.

And research Nurman (2017) the results of his research regarding the difference in the effect of deep breathing therapy and progressive muscle relaxation therapy on blood pressure, there are also differences in the decrease in systolic and diastolic blood pressure in respondents after being given deep breathing therapy and progressive muscle relaxation therapy. So, in general, the results of this study are in line with the theory's truth regarding relaxation techniques can reduce or lower blood pressure in patients with hypertension.

\section{The Effectiveness of Progressive Muscle Relaxation (PMR) with Slow Deep Breathing Exercise (SDBE) on Blood Pressure of Hypertensive Patients}

The difference in the mean decrease in blood pressure after being given an intervention between the PMR and SDBE interventions, it was found that the systolic blood pressure between the PMR and SDBE interventions after receiving the intervention for seven days, there was a change in blood pressure reduction that was not much different, the researchers concluded between the PMR and SDBE interventions there was no significant difference ineffectiveness. Critical blood pressure between the two groups shows that the probability value is greater than the significance level of $p=0.520(>0.05)$. The diastolic blood pressure of the intervention group PMR is more effective than the 
diastolic blood pressure of the intervention group SDBE. The probability value is smaller than the level of significance $=0.009(<0.05)$.

The results of this study are similar to the research conducted Ismansyah et al., (2019) There is a significant difference between progressive muscle relaxation interventions and slow deep airway interventions on systolic, pulse, and respiration. Progressive muscle relaxation intervention substantially affects systolic, diastolic, pulse, and body temperature. Compared with slow deep breathing intervention, the intervention has a more significant effect on breathing than the progressive muscle intervention..

\section{The Effectiveness of Progressive Muscle Relaxation (PMR) with Slow Deep Breathing Exercise, Progressive Muscle Relaxation (SDBE PMR) on Blood Pressure of Patients with Hypertension}

The difference in the average decrease in blood pressure after being given an intervention between the PMR intervention and the SDBE PMR showed a reduction in systolic blood pressure, which was not much different. The researchers concluded between the PMR and SDBE PMR interventions; there was no significant difference in effectiveness on changes in blood pressure; this can be seen in the probability value more effective than the significance level of $p=0.226$ ( $>0.05$ ). On diastolic blood pressure, the researcher concluded that there was also no significant difference in effectiveness on blood pressure. It can be seen that the probability value is greater than the significance level of $p=0.970$ (> 0.05). Researchers have not found any studies that compare the effectiveness of progressive muscle relaxation (PMR) with a slow deep breathing exercise, progressive muscle relaxation (SDBE PMR) on blood pressure in patients with hypertension, so researchers cannot compare it with other studies.

Effectiveness of Slow Deep Breathing Exercise (SDBE) with Slow Deep Breathing Exercise, Progressive Muscle Relaxation (SDBE PMR) on Blood Pressure of Patients with Hypertension

PMR, there is no significant difference in the effectiveness of changes in the average change in systolic blood pressure. It can be seen that the probability value is greater than the significance level of $p=0.427$ (> 0.05). The SDBE PMR intervention diastolic blood pressure is more effective than the SDBE intervention diastolic blood pressure because there is a significant difference in the average value of blood pressure. It can be seen that the probability value is smaller than the significance level. $=0.031(<0.05)$ Researchers have not found any studies that differentiate between the effectiveness of Slow Deep Breathing Exercise (SDBE) with Slow Deep Breathing Exercise, Progressive Muscle Relaxation (SDBE PMR), which is carried out simultaneously on the blood pressure of people with hypertension, so researchers also cannot compare it with other studies.

Effective Time of Lowering Blood Pressure after Progressive Muscle Relaxation (PMR), Slow Deep Breathing Exercise (SDBE) and Slow Deep Breathing Exercise Progressive Muscle Relaxation (SDBE PMR) Interventions on Blood Pressure of Patients with Hypertension

In general, there was a change in the decrease in systolic blood pressure in both the PMR, SDBE, and SDBE PMR intervention groups for seven days. If you look at the adequate time, the SDBE PMR intervention group did not see when the proper time for reducing blood pressure occurred. The proper time could only be seen from the PMR and 
SDBE groups, which happens on day 3. In general, there is also a change in blood pressure reduction in the PMR, SDBE, and SDBE PMR intervention groups. If you look at the adequate time for seven days from the three intervention groups, it is not visible when the intervention is effective. The researcher assumed that the effective time of the three intervention groups, both systolic and diastolic blood pressure, was not visible because all respondents had relatively denser activities than regular days at the study time.

\section{CONCLUSION}

There is a significant difference between systolic and diastolic blood pressure values before and after Progressive Muscle Relaxation (PMR), slow Deep Breathing Exercise (SDBE), and Slow Deep Breathing Exercise Progressive Muscle Relaxation (SDBE PMR) interventions. Progressive Muscle Relaxation (PMR), Slow Deep Breathing Exercise (SDBE), and Slow Deep Breathing Exercise Progressive Muscle Relaxation (SDBE PMR) are effective in lowering blood pressure in patients with hypertension. There was no significant difference in the decrease in systolic blood pressure between respondents who received Progressive Muscle Relaxation (PMR) therapy and respondents who received Slow Deep Breathing Exercise (SDBE) treatment after the intervention.

\section{SUGGESTIONS}

\section{For Health Center Institutions}

Health center staff participate in training on complementary therapies, especially Slow Deep Breathing Exercise (SDBE) and Progressive Muscle Relaxation (PMR), and can provide counseling to the public, especially people with hypertension, about Slow Deep Breathing Exercise (SDBE) and Progressive Muscle Relaxation (PMR) therapy

\section{For Further Research}

It is necessary to develop further research in this study because there are no confounding variables studied or tested; therefore, confounding variables are needed to be researched or tested; researchers in conducting research do not look at respondents' stress factors, it is hoped that further researchers can pay attention to respondents' stress factors because stress while being a respondent significantly affects blood pressure, further research needs to be developed on relaxation techniques, especially SDBE and PMR which are combined or compared with other complementary nursing therapies that focus on exercise in clients with hypertension.

\section{REFERENCES}

Akhriansyah, M. (2019). Pengaruh Progressive Muscle Relaxation (PMR) terhadap Penurunan Tekanan Darah pada Lansia Hipertensi di Panti Sosial Tresna Wherda Palembang Provinsi Sumatera Selatan Tahun 2018. Jurnal Ilmiah Universitas Batanghari Jambi, 19(1), 11. https://doi.org/10.33087/jiubj.v19i1.544

Al-Mahdi, E. A. R., Ros, A. L., Moya, R. R. M., \& Gómez, J. L. Z. (2021). Hypertension and the Heart. Medicine (Spain), 13(36), 2089-2098. https://doi.org/10.1016/j.med.2021.06.013

Andari, F., Vioneery, D., Panzilion, P., Nurhayati, N., \& Padila, P. (2020). Penurunan Tekanan Darah pada Lansia dengan Senam Ergonomis. Journal of Telenursing (JOTING), 2(1), 81-90. https://doi.org/https://doi.org/10.31539/joting.v2i1.859 
Andri, J., Permata, F., Padila, P., Sartika, A., \& Andrianto, M. B. (2021). Penurunan Tekanan Darah pada Pasien Hipertensi Menggunakan Intervensi Slow Deep Breathing Exercise. Jurnal Keperawatan Silampari, 5(1), 255-262. https://doi.org/https://doi.org/10.31539/jks.v5i1.2917

Andri, J., Padila, P., Sartika, A., Andrianto, M. B., \& Harsismanto, J. (2021). Changes of Blood Pressure in Hypertension Patients Through Isometric Handgrip Exercise. JOSING: Journal of Nursing and Health, 1(2), 54-64. https://doi.org/10.31539/josing.v1i2.2326

Andri, J., Waluyo, A., Jumaiyah, W., \& Nastashia, D. (2018). Efektivitas Isometric Handgrip Exercise dan Slow Deep Breathing Exercise terhadap Perubahan Tekanan Darah pada Penderita Hipertensi. Jurnal Keperawatan Silampari,2(1), 371-384. https://doi.org/10.31539/jks.v2i1.382

Anggreini, S. N., \& Alfianur, A. (2021). Pengaruh Slow Deep Breathing (SDB) Dapat Menurunkan Tekanan Darah pada Penderita Hipertensi Primer. Holistik Jurnal Kesehatan, 15(2), 340-347. https:/doi.org/10.33024/hjk.v15i2.5182

Atmojo, J. T., Putra, M. M., Astriani, N. M. D. Y., Dewi, P. I. S., \& Bintoro, T. (2019). Efektifitas Terapi Relaksasi Benson terhadap Tekanan Darah pada Penderita Hipertensi. Interest: Jurnal Ilmu Kesehatan, 8(1), 53-60. https://doi.org/10.37341/interest.v8i1.117

Febrianingrum, A. M., Norlinta, S. N. O., \& Aisyah, N. U. (2021). Study Narrative Review pengaruh Slow Deep Breathing Exercise terhadap Penurunan Tekanan Darah Penderita Hipertensi Derajat I. Universitas 'Aisyiyah Yogyakarta. http://digilib.unisayogya.ac.id/id/eprint/5610

Harsismanto, J., Andri, J., Payana, T., Andrianto, M. B., \& Sartika, A. (2020). Kualitas Tidur Berhubungan dengan Perubahan Tekanan Darah pada Lansia. Jurnal Kesmas Asclepius, 2(1), 1-11. https://doi.org/https://doi.org/10.31539/jka.v2i1.1146

Irawan, O. (2017). Pengaruh Terapi Rendam Air Hangat pada Kaki Sambil Mendengarkan Musik Klasik terhadap Penurunan Tekanan Darah pada Penderita Hipertensi di Wilayah Kerja Puskesmas Basuki Rahmad Kota Bengkulu. Poltekkes Kemenkes BKL

Ismansyah, I., Parellangi, A., Firdaus, R., Wiadiastuti, W., \& Prawita, H. (2019). The Effect of Progressive Muscle Relaxation and Slow Deep Breathing Toward Vital Signs of Patients' Hypertension in The Working Area of Bengkuring Medical Center (Puskesmas). Asian Community Health Nursing Research, 1(2), 33. https://doi.org/10.29253/achnr.2019.13320

Kementerian Kesehatan RI. (2018). Laporan Riskesdas 2018. In Laporan Nasional Riskesdas 2018 (Vol. 53, Issue 9)

Moura, M. P. (2019). Non-Pharmacological Treatment For Hypertension: A Systematic Review. Journal of Hypertension, 37, e251-e252. https://doi.org/10.1097/01.hjh.0000573216.49484.4c

Nurman, M. (2017). Efektifitas antara Terapi Relaksasi Otot Progresif dan Teknik Relaksasi Nafas Dalam terhadap Penurunan Tekanan Darah pada Penderita Hipertensi di Desa Pulau Birandang Wilayah Kerja Puskesmas Kampar Timur Tahun 2017. Jurnal Ners, 1(2), 108-126. https://doi.org/10.31004/jn.v1i2.122

Oni, O. O., Adebiyi, A. A., Aje, A., \& Akingbola, T. S. (2020). Impact of Relative Systemic Hypertension on the Heart in Sickle Cell Anaemia. Indian Heart Journal, 72(3), 205-208. https://doi.org/10.1016/j.ihj.2020.05.007 
Paduszyńska, A., Banach, M., Maciejewski, M., Dąbrowa, M., \& Bielecka-Dabrowa, A. (2020). The Outcomes of Hypertension Treatment Depending on Gender in Patients Over 40 Years of Age. Menopausal Review, 19(4), 174-178. https://doi.org/10.5114/pm.2020.101947

Permata, F., Andri, J., Padila, P., Andrianto, M., \& Sartika, A. (2021). Penurunan Tekanan Darah pada Pasien Hipertensi Menggunakan Teknik Alternate Nostril Breathing Exercise. Jurnal Kesmas Asclepius, 3(2), 60-69. https://doi.org/10.31539/jka.v3i2.2973

Rosdiana, I., \& Cahyati, Y. (2019). Effect of Progressive Muscle Relaxation (PMR) on Blood Pressure among Patients with Hypertension. International Journal of Advancement in Life Sciences Research, 2(1), 28-35. https://doi.org/10.31632/ijalsr.2019v02i01.005

Sartika, A., Betrianita, B., Andri, J., Padila, P., \& Nugrah, A. V. (2020). Senam Lansia Menurunkan Tekanan Darah pada Lansia. Journal of Telenursing (JOTING), 2(1), 11-20. https://doi.org/10.31539/joting.v2i1.1126

Sartika, A., Wardi, A., \& Sofiani, Y. (2018). Perbedaan Efektivitas Progressive Muscle Relaxation (PMR) dengan Slow Deep Breathing Exercise (SDBE) terhadap Tekanan Darah Penderita Hipertensi. Jurnal Keperawatan Silampari, 2(1), 356-370. https://doi.org/10.31539/jks.v2i1.380

Setyaningrum, N., Permana, I., \& Yuniarti, F. A. (2018). Progressive Muscle Relaxation dan Slow Deep Breathing pada Penderita Hipertensi. Jurnal Persatuan Perawat Nasional Indonesia (JPPNI), 2(1), 33-43. https://doi.org/10.32419/jppni.v2i1.81

Shrestha, J., Marasine, N. R., Lamichhane, R., Marasini, N. R., \& Sankhi, S. (2021). Attitude and Self-Care Practice on Hypertension Among Antihypertensive Medication Users in a Tertiary Care Hospital Nepal. SAGE Open Medicine, 9, 205031212110407. https://doi.org/10.1177/20503121211040707

Siddiqui, M. A., Mittal, P. K., Little, B. P., Miller, F. H., Akduman, E. I., Ali, K., Sartaj, S., \& Moreno, C. C. (2019). Secondary Hypertension and Complications: Diagnosis and Role of Imaging. RadioGraphics, 39(4), 1036-1055. https://doi.org/10.1148/rg.2019180184

Sudarso, S., Kusbaryanto, K., Khoiriyati, A., \& Huriah, T. (2019). Efektivitas Pemberian Intervensi Gerakan Sholat terhadap Penurunan Tekanan Darah pada Lansia dengan Hipertensi. Jurnal Keperawatan, 12(1), 76-86. http://repository.umy.ac.id/handle/123456789/30519

Tim Riskesdas 2018, B. (2019). Laporan Provinsi Bengkulu RIKESDAS 2018. Lembaga Penerbit Balitbangkes. https://www.litbang.kemkes.go.id/laporan-riset-kesehatandasar-riskesdas/

Wulandari, R., \& Puspita, S. (2019). Hubungan Pengetahuan, Dukungan Keluarga, dan Peran Petugas Kesehatan dengan Kepatuhan Penderita Hipertensi dalam Menjalani Pengobatan. Jurnal 'Aisyiyah Medika, 4(3). https://doi.org/10.36729/jam.v4i3.206

Zainuddin, R., Aliwu, A. F., Rachmawaty, R., \& Syam, Y. (2018). Efektivitas Progressive Muscle Relaxation terhadap Tekanan Darah pada Penyakit Hipertensi. Strada Jurnal Ilmia Kesehatan, 7(2), 42-46. https://doi.org/10.30994/sjik.v7i2.169 